\title{
Influence of meteorological factors on rockfall occurrence in a middle mountain limestone cliff
}

\author{
Julie D'Amato ${ }^{1}$, Didier Hantz ${ }^{1}$, Antoine Guerin ${ }^{3}$, Michel Jaboyedoff ${ }^{3}$, Laurent Baillet ${ }^{1}$, and Armand Mariscal ${ }^{1,2}$ \\ ${ }^{1}$ Université Grenoble Alpes, ISTerre, 38041 Grenoble, France \\ ${ }^{2}$ IRD, ISTerre, 38041 Grenoble, France \\ ${ }^{3}$ Center for Research on Terrestrial Environment (CRET), Faculty of Geosciences and Environment, University of Lausanne, \\ Unil-Mouline, Geopolis, 1015 Lausanne, Switzerland
}

Correspondence to: Didier Hantz(didier.hantz@ujf-grenoble.fr)

Received: 26 November 2015 - Published in Nat. Hazards Earth Syst. Sci. Discuss.: 21 December 2015

Accepted: 22 February 2016 - Published: 15 March 2016

\begin{abstract}
The influence of meteorological conditions on rockfall occurrence has been often highlighted, but knowledge of it is still not sufficient due to the lack of exhaustive and precise rockfall databases. In this study, rockfalls have been detected in a limestone cliff by annual terrestrial laser scanning, and dated by photographic survey over a period of 2.5 years. A near-continuous survey (one photo every $10 \mathrm{~min}$ ) with a wide-angle lens has made it possible to date 214 rockfalls larger than $0.1 \mathrm{~m}^{3}$, and a monthly survey with a telephoto lens has dated 854 rockfalls larger than $0.01 \mathrm{~m}^{3}$. Analysis of the two databases shows that the rockfall frequency can be multiplied by a factor as high as 7 during freeze-thaw episodes and 26 when the mean rainfall intensity (since the beginning of the rainfall episode) is higher than $5 \mathrm{~mm} \mathrm{~h}^{-1}$. Based on these results, a three-level scale has been proposed for predicting the temporal variations of rockfall frequency. The more precise database and freeze-thaw episode definition make it possible to distinguish different phases in freeze-thaw episodes: negative temperature cooling periods, negative temperature warming periods and thawing periods. It appears that rockfalls occur more frequently during warming and thawing periods than during cooling periods. It can be inferred that rockfalls are caused by thermal ice dilatation rather than by dilatation due to the phase transition. But they may occur only when the ice melts, because the cohesion of the ice-rock interface can be sufficient to hold the rock compartment which has been cut.
\end{abstract}

\section{Introduction}

Rockfalls are sudden phenomena, usually non-predictable in time but sometimes in space, which can cause human or material damages. The geological and morphological context of a given site affects the rockfall activity, but rockfalls can be triggered by external factors (Cruden and Varnes, 1996) such as meteorological factors (see references in Table 2), earthquakes (Kobayashi et al., 1990; Malamud et al., 2004; Yin et al., 2009), volcanic eruptions (Hale et al., 2009, DeRoin and McNutt, 2012), sea waves (Rosser et al., 2005) and human activity. Several studies have highlighted the influence of these different triggering factors, but triggering mechanisms are still not well understood or quantified, especially considering the influence of meteorological factors. We need to better understand the triggering mechanisms of rockfalls, to enhance the quantitative assessment of rockfall hazard and the prediction of high-hazard periods according to the meteorological forecast. Moreover, this is an important step to assess the influence of climate change on rockfall hazard (Huggel et al., 2012; Sass and Oberlechner, 2012).

Rockfalls are a result of a long geological process (tectonic, weathering, etc.) (Viles, 2013), but the fall is sudden. The most asked question is, why does the rock fall at a given time? Behind this, the real question is, what makes it fall (what factors), and how (what mechanisms)? For a meteorological factor, several physical mechanisms can be involved, which can manifest as rockfalls initiated by a slide or a topple (Luckman, 1976). In Table 1, we propose some physical processes associated with different meteorological events, which 
Table 1. Meteorological factors and triggering mechanisms.

\begin{tabular}{|c|c|c|}
\hline Weather event & Processes proposed for rockfall triggering & Relevant meteorological parameters \\
\hline \multirow{4}{*}{$\begin{array}{l}\text { Rainfall } \\
\text { (intense or } \\
\text { prolonged) }\end{array}$} & Water pressure in rock joint & Intensity $\left(\mathrm{mmh}^{-1}\right)$, amount $(\mathrm{mm})$ \\
\hline & Clay swelling in rock joint & \\
\hline & Dissolution (chemical action) & Duration (h) \\
\hline & Leaching (mechanical action) & \\
\hline \multirow[t]{3}{*}{ Freeze-thaw } & $\begin{array}{l}\text { Ice frost wedging: ice pressure due ice formation } \\
\text { (confined dilatation) }+ \text { sealing of cracks } \\
\text { leading to water pressure }\end{array}$ & $\begin{array}{l}\text { Negative temperature }\left({ }^{\circ} \mathrm{C}\right) \text {, } \\
\text { negative gradient }\left({ }^{\circ} \mathrm{Ch}^{-1}\right)\end{array}$ \\
\hline & $\begin{array}{l}\text { Ice thermal wedging: ice pressure due } \\
\text { to confined thermal dilatation }\end{array}$ & $\begin{array}{l}\text { Negative temperature }\left({ }^{\circ} \mathrm{C}\right) \text {, } \\
\text { positive gradient }\left({ }^{\circ} \mathrm{Ch}^{-1}\right)\end{array}$ \\
\hline & Ice melting: loss of cohesion & Positive temperature $\left({ }^{\circ} \mathrm{C}\right)$ \\
\hline Snow and ice melt & Water pressure in rock joint & $\begin{array}{l}\text { Positive temperature }\left({ }^{\circ} \mathrm{C}\right) \text { and gradient }\left({ }^{\circ} \mathrm{Ch}^{-1}\right) \text {, } \\
\text { solar radiation }\left(\mathrm{W} \mathrm{m}^{-2}\right)\end{array}$ \\
\hline Sunshine & Thermal stresses which propagate cracks & Temperature $\left({ }^{\circ} \mathrm{C}\right)$, solar radiation $\left(\mathrm{W} \mathrm{m}^{-2}\right)$ \\
\hline
\end{tabular}

can trigger a rockfall, and the associated relevant meteorological parameters.

Most works concerning these factors are based either on a single event study (Yamagishi, 2000; Wei et al., 2014), or on a rockfall inventory. Some examples of studies based on a rockfall inventory are given in Table 2 . They show the influence of meteorological factors, but it is not possible to conclude on a dominating triggering factor, partly because these studies present several disparities concerning:

- the geological and climatic context (from coastal to high mountain);

- the size and completeness of the rockfall inventory (from 10 to almost 1000 events);

- the precision of dating (from day to year);

- the precision of meteorological data, in time and space (frequency of the measures, distance to the site);

- the method of analysis, e.g. thawing periods not precisely defined.

This study deals with a quasi-exhaustive rockfall inventory, obtained by Terrestrial Laser Scanner (TLS), now generally used for rockfall surveys (see reviews in Jaboyedoff et al., 2012; Abellan et al., 2014), combined with a photographic survey. The study site is a cliff with homogeneous lithology, avoiding geological, geomorphological and climatic bias. We use two levels of dating precision. In addition, we have defined new precise meteorological parameters in order to better evaluate triggering processes related to meteorological factors, especially considering freeze and thaw which are not often clearly defined in the literature.

\section{Study site}

The Mont Saint-Eynard (MSE) is located northeast of Grenoble, Isère, French Alps (Fig. 1). It is a long double cliff, making up the western border of the Isère Valley and the oriental edge of the Chartreuse Massif. The lower cliff is $240 \mathrm{~m}$ high, separated from the $120 \mathrm{~m}$ high upper cliff by a ledge covered with forest. The upper cliff consists of massive limestone (bed thickness $>1 \mathrm{~m}$ ) of the Tithonian stage. The lower cliff consists of fractured thin bedded $(10-50 \mathrm{~cm})$ limestone, of the Sequanian stage. The bedding planes dip inside the cliff. This anaclinal configuration, completed by subvertical fractures, produces overhanging compartments falling mainly by toppling.

This SW-NE trending cliff belongs to the eastern side of the Sappey syncline, which dips north in the direction N10. Two subvertical dextral faults cut the cliff (Gidon, 1990), with a direction of about N60-70. Note that the global direction of the Saint Eynard Cliff (N45) is different from the syncline axis (N10).

A $750 \mathrm{~m}$ long zone of interest (photograph in Fig. 1) has been yearly surveyed by TLS since 2009 (Guerin et al., 2014). This study focuses on the MSE lower cliff for several reasons:

- high rockfall activity compared to the upper cliff (Fig. 1);

- large volume range: from $0.001 \mathrm{~m}^{3}$ to more than $1000 \mathrm{~m}^{3}$ (exceptional event);

- lithological homogeneity;

- the entire cliff faces south: homogeneous sun exposition. 


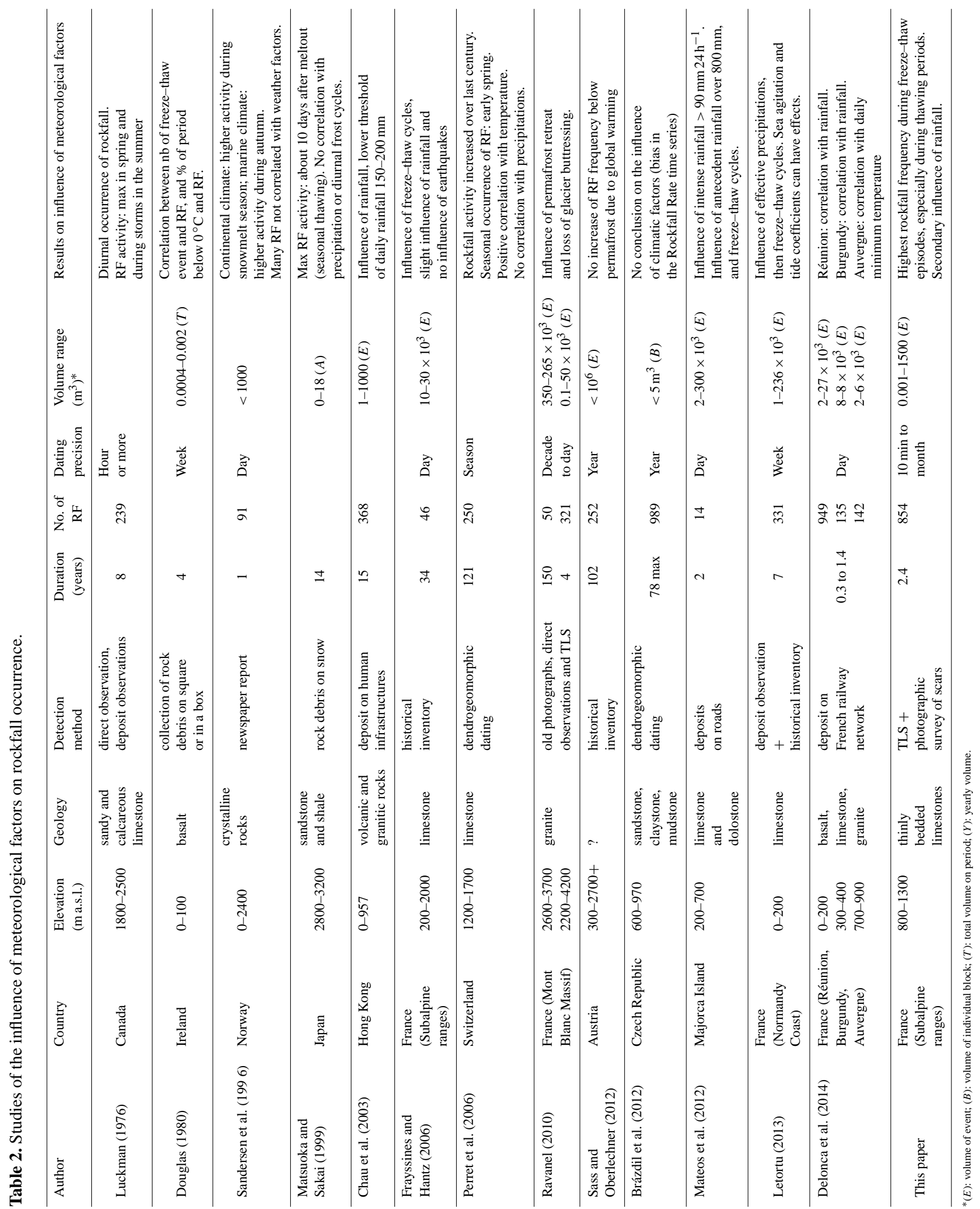



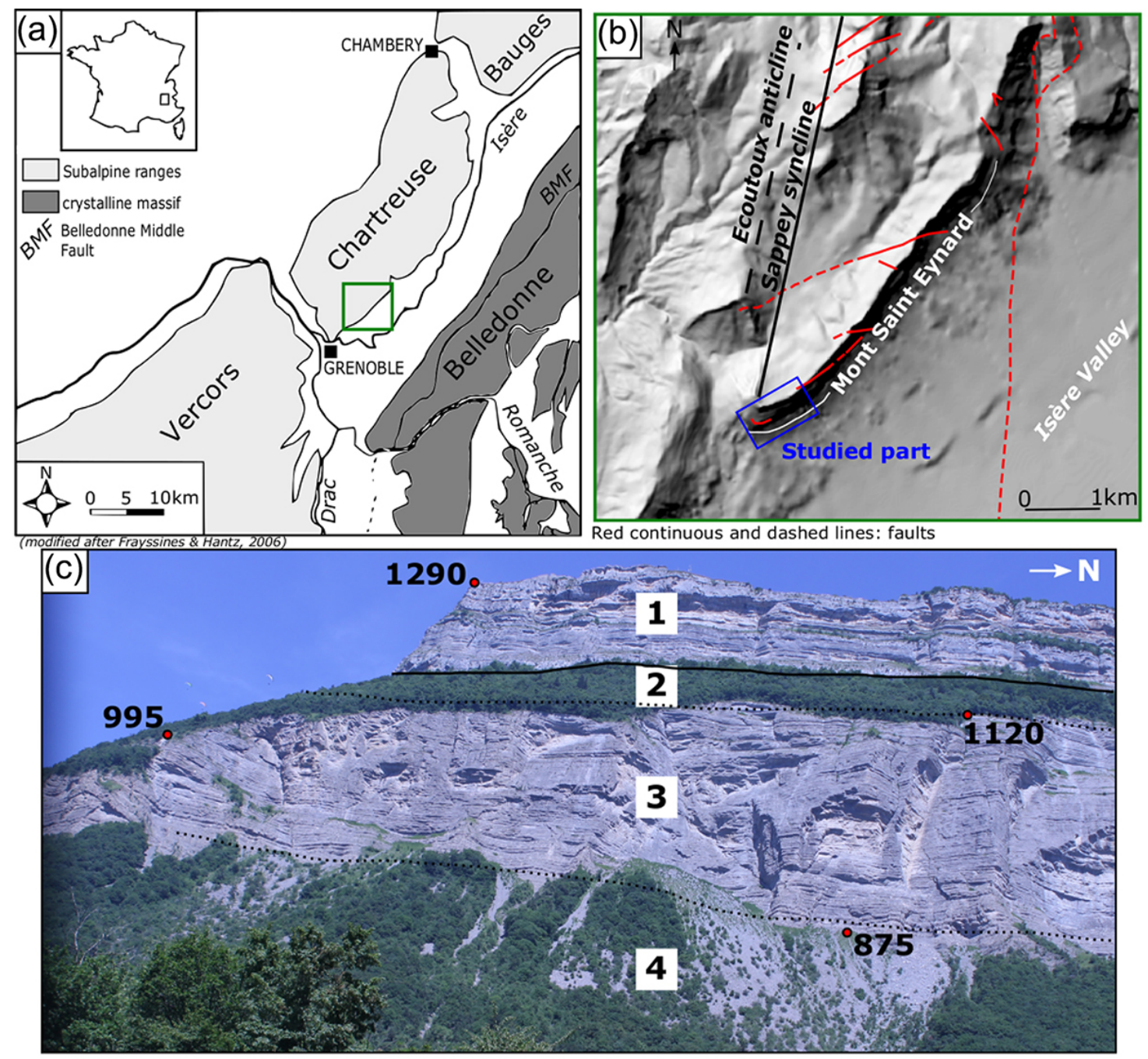

\begin{tabular}{|c|c|c|c|c|c|c|c|c|}
\hline d) & Stage/ formations & Lithology & $\begin{array}{l}\text { Slope } \\
\text { angle }\end{array}$ & $\begin{array}{c}\text { Bedding } \\
\text { planes (dip } \\
\text { dir/dip) } \\
\end{array}$ & $\begin{array}{c}\text { Main } \\
\text { Joint sets }\end{array}$ & Morphology & $\begin{array}{l}\text { Geotechnical } \\
\text { properties }\end{array}$ & $\begin{array}{c}\text { Rockfall } \\
\text { frequency } \\
\left(>0.1 \mathrm{~m}^{3}\right)\end{array}$ \\
\hline 1 & $\begin{array}{l}\text { Tithonian - upper } \\
\text { Kimmeridgian }\end{array}$ & $\begin{array}{l}\text { Lithographic massive } \\
\text { limestone. Thickening of beds } \\
\text { from bottom to top. Thin } \\
\text { marly beds at the bottom. }\end{array}$ & $80^{\circ} \mathrm{SE}$ & $330 / 60$ & $\begin{array}{l}\text { subvertical, } \\
\text { N60 and } \\
\text { N120 }\end{array}$ & $\begin{array}{l}120 \mathrm{~m} \text { high cliff, } \\
\text { overhanging beds, } \\
\text { smooth linear } \\
\text { horizontal profile }\end{array}$ & $\begin{array}{c}\mathrm{BT}=30-120 \mathrm{~cm} \\
\sigma \mathrm{c}>100 \mathrm{MPa}\end{array}$ & $\begin{array}{c}\text { Fn }\left(0.1 \mathrm{~m}^{3}\right)=0.5 \\
/ \mathrm{yr} / \mathrm{hm}^{2}\end{array}$ \\
\hline 2 & $\begin{array}{c}\text { Lower } \\
\text { Kimmeridgian }\end{array}$ & $\begin{array}{l}\text { Clayey limestone with } \\
\text { decimetric marly beds. }\end{array}$ & $40^{\circ} \mathrm{SE}$ & $\mathrm{N}$ & & Forested slope & $\begin{aligned} \mathrm{BT} & =10-50 \mathrm{~cm} \\
\sigma \mathrm{c} & =20-50 \mathrm{MPa}\end{aligned}$ & \\
\hline 3 & $\begin{array}{l}\text { "Sequanian" (basal } \\
\text { Kimmeridgian and } \\
\text { terminal Oxfordian) }\end{array}$ & $\begin{array}{l}\text { Thin beds of lithographic } \\
\text { limestone, dark grey, scarce } \\
\text { marly jointed. Cyclic } \\
\text { sedimentation. }\end{array}$ & $80^{\circ} \mathrm{SE}$ & $345 / 35$ & $\begin{array}{l}\text { subvertical, } \\
\text { N90 and } \\
\text { N60 }\end{array}$ & $\begin{array}{l}240 \mathrm{~m} \text { high cliff with } \\
\text { horizontal spurs } \\
\text { and recesses, } \\
\text { overhanging beds }\end{array}$ & $\begin{array}{l}\mathrm{BT}=10-30 \mathrm{~cm} \\
\sigma \mathrm{c}=70-100 \mathrm{MPa}\end{array}$ & $\begin{array}{c}\text { Fn }\left(0.1 \mathrm{~m}^{3}\right)=11 \\
/ \mathrm{yr} / \mathrm{hm}^{2}\end{array}$ \\
\hline 4 & Upper Oxfordian & $\begin{array}{l}3 \text { to } 1 \mathrm{~m} \text { thick schistose marl, } \\
\text { altemating with marly limestone } \\
\text { beds. Progressive marl- } \\
\text { limestone transition. Cyclic } \\
\text { sedimentation }\end{array}$ & $35^{\circ} \mathrm{SE}$ & $\mathrm{N}$ & & $\begin{array}{l}\text { Slope covered with } \\
\text { scree, gullies, } \\
\text { forests }\end{array}$ & $\begin{array}{l}\mathrm{BT}=5-50 \mathrm{~cm} \\
\sigma \mathrm{c}=30-50 \mathrm{MPa}\end{array}$ & \\
\hline
\end{tabular}

Figure 1. (a) Simplified geological map of the subalpine ranges. (b) DEM of the studied zone, with structural features. (c) Photograph of the studied part of the Mont Saint Eynard. Dashed lines: supposed geological limit; continuous line: confirmed geological limit. (d) Geological and geotechnical information (Chardon, 1987; MELTT, 1997). 
The climate of the Grenoble town is characterized by a mean annual precipitation of $934 \mathrm{~mm}$, a mean minimal temperature of $6^{\circ} \mathrm{C}$ and a mean maximal temperature of $16^{\circ} \mathrm{C}$ (measured from 1981 to 2010 at an elevation of $200 \mathrm{~m}$ ). At the elevation of the MSE lower cliff (800-1050 m), the precipitation is higher: the gradient is of $28 \mathrm{~mm}$ year $^{-1} / 100 \mathrm{~m}$ in this zone (Douguédroit and Saintignon, 1984). Also, the mean annual temperature is lower than in Grenoble: a temperature gradient of $0.6^{\circ} \mathrm{C} / 100 \mathrm{~m}$ is usually considered, but our temperature measures on the cliff show a lower gradient of $0.3^{\circ} \mathrm{C} / 100 \mathrm{~m}$, due to the southern exposition of the cliff and the morphology of the Isère valley (Jail, 1966a).

\section{Methodology}

\subsection{Rockfall detection by TLS}

Rockfall detection is carried out by a diachronic comparison of point clouds of the cliff acquired in November 2012 and April 2015, by terrestrial laser scanning. A laser scanner Optech Ilris-LR has been used (Optech, 2015). Four acquisitions were carried out at the dates: 16 November 2012, 26 November 2013, 15 July 2014 and 22 April 2015.

The raw point clouds are cleaned, in order to remove vegetation noise and keep only the rock surface (Abellan et al., 2014). They are georeferenced using a georeferenced $1 \mathrm{~m}$ spacing DEM (from the IGN, French national institute of geography) of the site. A mesh is built with the point cloud acquired in year $Y$. For detection of rockfalls, this mesh is registered with the point cloud of the previous year, $Y-1$, using the software 3DReshaper ${ }^{\odot}$. Positive deviations higher than $10 \mathrm{~cm}$ are considered as rockfalls. The point clouds defining a fallen compartment are meshed, making it possible to calculate the volume of the compartment and to get dimensions and gravity centre. The method is described in more detail in Guerin et al. (2014). It allows exhaustive detection of rockfalls larger than $0.05 \mathrm{~m}^{3}$.

\subsection{Rockfall dating by photographic survey}

A photographic survey from $1 \mathrm{~km}$ of the cliff makes it possible to date the occurred rockfalls. It consists of highresolution photographs taken every several weeks (periodic survey) and lower resolution photographs taken every $10 \mathrm{~min}$ (continuous survey, with an autonomous snapping system). Technical information is given in the Table 3 .

854 rockfalls have been detected in the period between 16 November 2012 and 22 April 2015 (887 days). Each rockfall was dated by comparing high-resolution photographs, taken every 2 to 11 weeks ( 37 days on average). They constitute database 1 (DB1). Rockfalls were considered only when there were evident clues of the fall on the photographs: visible scar, obvious change in colour, shadow or relief (Chanut et al., 2011).

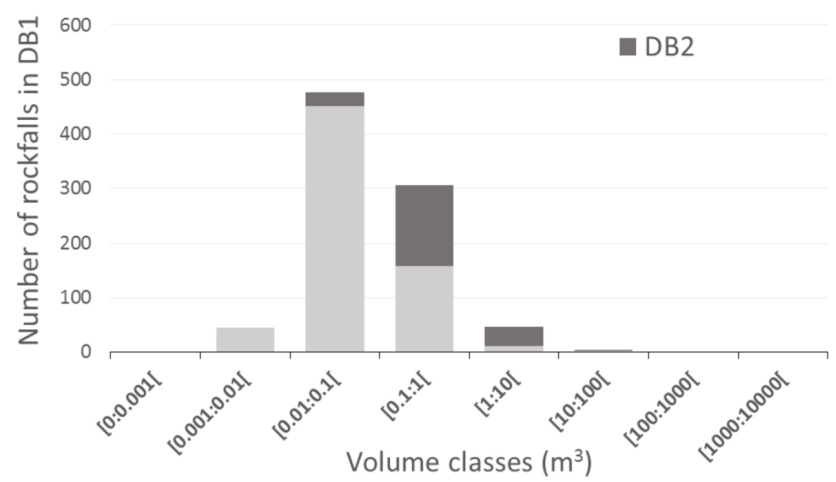

Figure 2. Volume distribution of the two databases.

From 1 February 2013 to 22 April 2015, this periodic highresolution photographic survey was complemented by a lowresolution quasi-continuous survey (one photo every $10 \mathrm{~min}$ ). 214 rockfalls have thus been dated more precisely in intervals of between $10 \mathrm{~min}$ and 25 days. They constitute database 2 (DB2). Only $25 \%$ of the DB1 events were dated precisely, mainly due to the photographic resolution: the smallest rockfalls are hardly identified on low-resolution photographs. Schematically, one pixel of a photograph from the continuous survey corresponds to a surface area of $0.04 \mathrm{~m}^{2}$. It is thus not surprising that the smallest rockfalls of DB2 have volumes of $0.04 \mathrm{~m}^{3}$, while the smallest ones in DB1 have volume of $0.002 \mathrm{~m}^{3}$. The volume distributions for the two databases are given on Fig. 2. Obviously, rockfalls occurring during the night cannot be dated with a precision better than about $12 \mathrm{~h}$. Moreover, the dating uncertainty may be higher due to the meteorological conditions: the entire cliff face or part of it can be hidden (clouds, fog, snow). On sunny days, strong shadows can also "mask" the compartment location for a long time. The dating uncertainty can also be due to technical issues: the snapping system sometimes stopped for several days. It ensues that only $70 \%$ of DB2 rockfalls (144 events) have been dated in periods of $10 \mathrm{~min}$ to $20 \mathrm{~h}$.

\subsection{Meteorological data acquisition and treatment}

\subsubsection{Meteorological data}

The meteorological data come from weather stations of the Météo France network around the cliff, and since February 2014, from temperature sensors which have been placed on the upper cliff (1290 m a.s.l.) and inside the rock.

Rainfall data are given by a rain gauge located $900 \mathrm{~m}$ from the cliff face, with an hourly frequency. The raw data correspond to the number of gauge runnel $(0.2 \mathrm{~mm})$ swaying per hour.

The valley temperature is measured at a station located around $2 \mathrm{~km}$ from the cliff face at an elevation of $245 \mathrm{~m}$. The temperature has been measured (each $10 \mathrm{~min}$ ) on the upper cliff (1290 m elevation) only since February 2014, with tem- 
Table 3. Technical information of rockfall databases.

\begin{tabular}{|c|c|c|c|c|c|c|c|c|c|c|}
\hline Database & Camera type & $\begin{array}{l}\text { Lens } \\
\text { focal } \\
\text { distance }\end{array}$ & $\begin{array}{l}\text { Sensor } \\
\text { size }\end{array}$ & $\begin{array}{l}\text { Approximate } \\
\text { pixel size }\end{array}$ & $\begin{array}{l}\text { Photo } \\
\text { precision }\end{array}$ & $\begin{array}{l}\text { Minimal } \\
\text { detected } \\
\text { volume } \\
\left(\mathrm{m}^{3}\right)\end{array}$ & $\begin{array}{l}\text { Photo } \\
\text { interval }\end{array}$ & $\begin{array}{l}\text { Dating } \\
\text { precision }\end{array}$ & $\begin{array}{l}\text { Number of } \\
\text { rockfalls }\end{array}$ & $\begin{array}{l}\text { Number of } \\
\text { days }\end{array}$ \\
\hline DB 1 & Nikon 50D & $300 \mathrm{~mm}$ & $6 \mathrm{Mpx}$ & $3 \mathrm{~cm}$ & High & 0.002 & Month & Low & 854 & 887 \\
\hline DB 2 & Canon EOS Rebel T3 1100D & $24 \mathrm{~mm}$ & $12 \mathrm{Mpx}$ & $21 \mathrm{~cm}$ & Low & 0.04 & $10 \mathrm{~min}$ & High & 214 & 810 \\
\hline
\end{tabular}

perature sensors in open rock joints $(2-4 \mathrm{~cm}$ opening) at a depth of about $10 \mathrm{~cm}$, and in two sealed boreholes at depths of 20 and $50 \mathrm{~cm}$. Because we study the action of the ice in rock joints, we have considered the air temperature in the open joints (almost always in the shade). To have a constant method to estimate this temperature at the elevation of the lower cliff, the mean temperature gradient has been determined between the valley temperature and the upper cliff temperature, over the period from February 2014 to April 2015. The value obtained $\left(0.003{ }^{\circ} \mathrm{Cm}^{-1}\right)$ is lower than the average temperature gradient usually known $\left(0.006^{\circ} \mathrm{Cm}^{-1}\right)$, due to the south exposition of the slope and the topographic setting, but close to the value obtained by Jail (1966a, b) for the MSE slope. The lower cliff temperature $T$ is estimated from the temperature gradient and the valley temperature, using

$T=T_{\mathrm{m}}-0.003\left(Z-Z_{\mathrm{m}}\right)$,

with $T_{\mathrm{m}}$ the temperature measured in the valley, $Z$ the mean elevation of the rockfall sources in the lower cliff $(900 \mathrm{~m})$, and $Z_{\mathrm{m}}$ the elevation of the measuring station.

\subsubsection{Definition of rainfall episodes}

Rainfall episodes have been defined in order to better estimate the influence of rain. The beginning of a rainfall episode is associated with the first record of the rain gauge following a given period without rain (Bertrand-Krajewski, 2007). This first record occurs when the runnel capacity $(0.2 \mathrm{~mm})$ is reached. It follows that, beside the uncertainty due to the recording frequency, there is a delay between the true beginning of a rainfall and the first record. Moreover, rainfalls smaller than $0.2 \mathrm{~mm}$ are not detected.

A rainfall episode begins when it begins to rain after a given length of time without rain (Bertrand-Krajewski, 2007). This length has been chosen so that the rainfall episodes are independent. We have considered that two rainfall episodes are independent if the effects of the first episode stop before the second episode begins (Fig. 3). The direct influence of rain starts when falling on the cliff, but we have to also take into account water which falls on the forested ledge, and goes through soil and rock to reach the cliff surface and flow on it. The period of influence has been chosen from field observation of water seepage on the cliff (photographs). We have assumed that after around $24 \mathrm{~h}$, the rainwater has entirely flown from the cliff (Fig. 3). 1st case:

rainfall 1 and rainfall 2 are two independent episodes

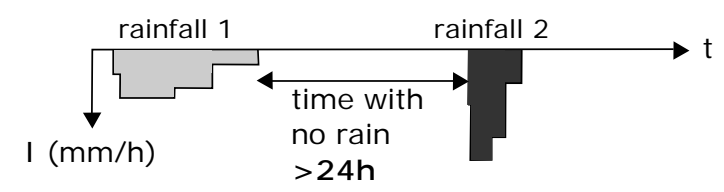

2nd case:

rainfall 1 and rainfall 2 are ONE independent episode

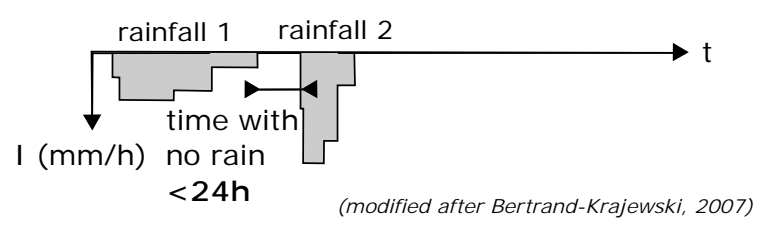

Figure 3. Schematic representation of the definition of an independent rainfall episode.

With this definition, 148 rainfall episodes during 2.4 years have been determined. The distribution of the duration of these episodes is given in Fig. 4. The total duration of the rainfall episodes represents $24 \%$ of the observation period.

The data do not distinguish between rainfall and snow, with both considered as precipitation (Bertrand-Krajewski, 2007). As a first approximation, we can assume that snow occurs when temperature is negative with precipitation. This concerns less than $1 \%$ of the precipitation time. So, snow falls were not considered.

\subsubsection{Definition of freeze-thaw episodes}

The influence of ice on rockfall occurrence can be explained by the pressure it exerts in rock discontinuities (Davidson and Nye, 1985; Walder and Hallet, 1985; Bost, 2008), either when the ice forms in a confined environment (joints, cracks or pores), or when it dilates during heating episodes. But it has also been observed that rockfalls frequently occur after a freezing period, when the temperature is positive (Matsuoka and Sakai, 1999). In order to investigate these processes, the freeze-thaw episodes have been divided into three period types: cooling periods (when the negative temperature decreases), warming periods (when temperature increases but 

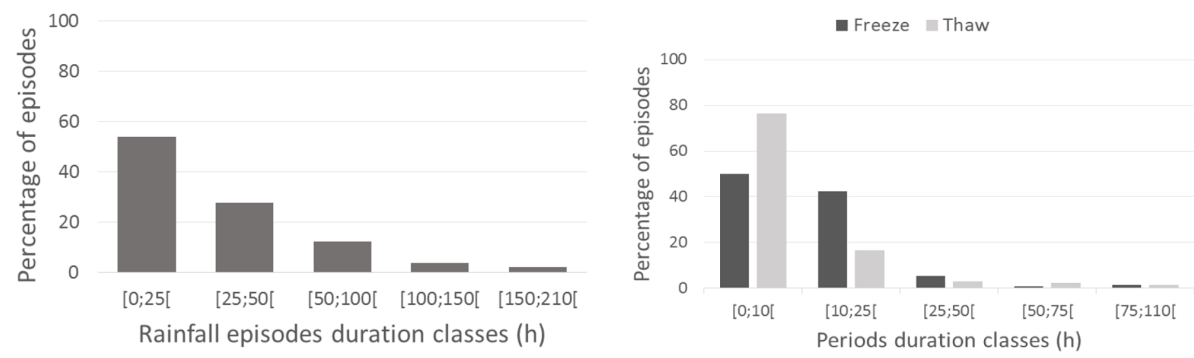

Figure 4. Distribution of rainfall episodes duration, and of freezing and thawing periods duration. More than $80 \%$ of thawing episodes are shorter than $12 \mathrm{~h}$, and almost $95 \%$ of thawing periods are shorter than $24 \mathrm{~h}$. Long thawing periods occurred only at the end of the winter, when freezing no longer occurs.

remains negative) and thawing periods (when temperature is positive and ice melts).

Our observations show that ice is produced where water seeps slowly on crack walls and when the temperature of the rock surface is negative. This accretion process can go on for several days because the temperature inside the rock mass remains positive, allowing water seepage and migration to continue (Tharp, 1987; Murton et al., 2006; Hallet, 2006). Assuming that water seepage in the rock mass is constant, it is considered that the ice production is reflected by the freezing potential (FP), which has been used by Matsuoka (1994) for studying the freeze depth and by Montagnat et al. (2010) for studying the formation of ice columns. For a freeze-thaw episode beginning at $t_{0}, \mathrm{FP}$ is defined by

$$
\begin{aligned}
& \text { If } \int_{t_{0}}^{t}(T \mathrm{f}-T(t)) \mathrm{d} t<0 \text {, then FP }=0 . \\
& \text { If } \int_{t_{0}}^{t}(T \mathrm{f}-T(t)) \mathrm{d} t>0 \text {, then FP }=\int_{t_{0}}^{t}\left(T_{\mathrm{f}}-T(t)\right) \mathrm{d} t,
\end{aligned}
$$

with $T_{\mathrm{f}}$ the freezing point of water $\left(0^{\circ} \mathrm{C}\right)$ and $T(t)$ the temperature at the time $t$. As a first approximation, we consider that the ice has entirely melted when FP returns to zero. This point defines the end of the freeze-thaw episode (Fig. 5). A freeze-thaw episode begins when the temperature becomes negative and no freeze-thaw episode is in progress (there is no more ice in the rock mass).

A freezing period begins when the temperature becomes negative $\left(t=t_{0}\right)$. The FP becomes positive. It ends when the temperature becomes positive again. At this point the FP starts to decrease. A freezing period may include several cooling and warming periods. During cooling periods, the thermal contraction of existing ice tends to decrease the ice pressure. On the other hand, ice expansion occurs during negative warming periods and is proportional to the temperature increase. Ice melting occurs when the temperature becomes positive (thawing period). A thawing period ends either when the temperature becomes negative again (new freeze period), or when FP reaches 0 (no more ice). Note that a freeze-thaw

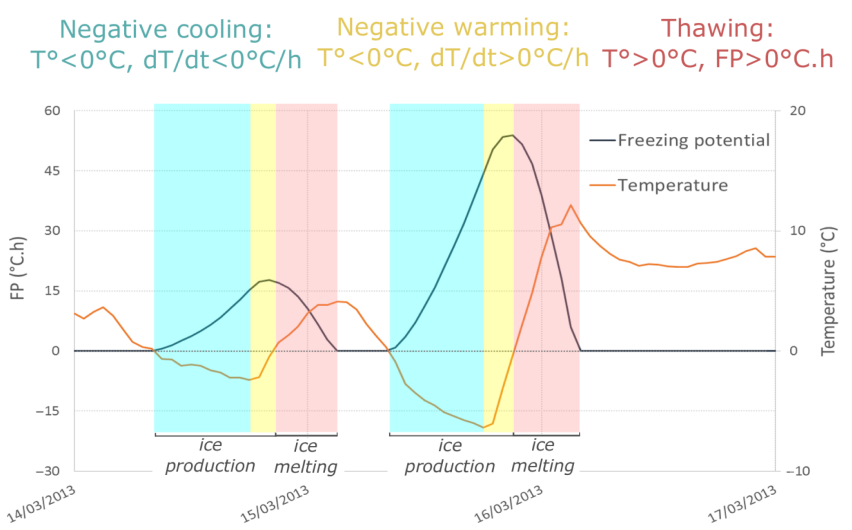

Figure 5. Definition of the three types of period within a freezethaw episode.

episode may include several freezing and thawing periods. Figure 4 show the distribution of the duration of freezing and thawing periods.

\section{Results}

\subsection{Results on DB1}

The rockfall frequency $\left(\mathrm{h}^{-1}\right)$ is given for each observation period in Fig. 7. As the dating periods have different lengths, we have not considered the absolute rainfall and freeze-thaw durations, but the time proportion of rainfall and freeze-thaw (respectively Rrd and Rftd) in each dating period. It was calculated by adding the durations of all the rainfall or freezethaw periods occurring during a dating period, and dividing the total rainfall or freeze-thaw duration by the length of the dating period (Fig. 6). In the same way, rainfall and freeze-thaw amount ratios (respectively Rra and Rfta) were determined for each dating period by adding all the rainfall amounts or the amplitudes of the FP variations (positive and negative), and dividing the sum by the length of the dating period (Fig. 6). Using these ratios, the relation between 
the rockfall frequency and the rainfall or freeze-thaw can be analysed in Fig. 7.

A first approach allows us to visually highlight the influence of some factors. It can be seen that the seven periods with the highest proportions of freeze-thaw, in duration or amount, give the highest rockfall frequencies. This indicates a strong influence of freeze-thaw on rockfall frequency. However, the influence of rainfall is not so clear. One can observe a factor of 10 between the highest and the lowest rockfall frequencies, which occur in periods with little rain.

In order to better quantify the relative influence of these factors, we used a multiple linear regression (Rakotomalala, 2015). This consists of explaining the rockfall frequency with rainfall and freeze-thaw duration ratios or amount ratios. The results are summarized in Table 4.

The test of the multiple regression, using the Fischer test, is significant: $F$ (duration) $=9.45$ and $F$ (amount) $=9.71$, in comparison with $F(0.05 ; 2 ; 20)=3.49$ at the 0.05 significance level, 2 degrees of freedom and around 20 observations (here 24). We can then consider that the determination coefficient for the multiple regression $R^{2}$, close to 0.5 , is also significant. This means that around $50 \%$ of the variability of rockfall frequency can be explained by the variability of rainfall and freeze-thaw duration or amount. This means that about $50 \%$ of the rockfalls are not triggered by rainfall or freeze-thaw and may occur at any time. The number of these rockfalls is then (from Tables 3 and 4) about 406 for an observation period of 887 days, and their frequency ("base" frequency) is about 0.019 rockfall $^{-1}$. The standardized regression coefficients help to estimate the "weight" of each variable on the variability of rockfall frequency. These are given in Table 4. We can see that the contribution of freeze-thaw $\left(\mathrm{Rftd}_{\mathrm{st}}\right.$ and $\left.\mathrm{Rfta}_{\mathrm{st}}\right)$ to explain the variability of the rockfall frequency is 5-7 times higher than those of rainfall.

Based on the Student test, the influence of freeze-thaw (duration ratio or amount ratio) is significant at the 0.05 significance level, but the hypothesis of no influence of the rain $\left(H_{0}\right)$ cannot be rejected. This clearly shows that freeze-thaw influence is more important than rain influence. It confirms the visual observations of Fig. 7. These results are consistent with Frayssines and Hantz (2006) who showed that freezethaw had a major influence on big historical rockfalls which occurred in subalpine limestone cliffs.

In order to distinguish different potential triggering mechanisms in the freeze-thaw cycle (Fig. 4), we determine the duration ratios of ice production (Ripd), negative warming (Rnwd) and thawing (Rtd), and also the amount ratios (Ripa, Rnwa, Rta) (Fig. 6). A multiple linear regression cannot be correctly performed on these types of data because of their collinearity (Rakotomalala, 2015): in fact, ice production, negative warming and thawing are not independent of each other. We performed the multiple regression on pairings formed by each of these parameters with rain $(r)$, in order to determine the parameter having the strongest influence on rockfall frequency. The highest determination coefficient and the lowest Akaike criterion (AIC) (Rakotomalala, 2015) were used to determine the best coupling. For both duration and amount ratios, thawing showed the best regression and correlation coefficients, and the lowest AIC. $R^{2}$ for the regression is again close to 0.5 (Table 4).

Considering the standardized regression coefficient, thawing shows a clear influence on rockfall frequency, with a contribution on rockfall frequency more than 7 times higher than rainfall. Again, the hypothesis of no rain influence $\left(H_{0}\right)$ cannot be rejected for the rain duration and amount, using a Student test. It can be noted that for all the multiple regressions, the constant of the regression represents the rockfall frequency for periods without either rainfall or freeze-thaw (base frequency), which cannot be estimated directly because there is no period without freeze-thaw or rainfall. Its value is around $0.021[0.011-0.031] \mathrm{h}^{-1}$ (Table 4). Note that the confidence interval includes the previously estimated value of 0.019 .

From this value, one can estimate for the observation periods including freeze-thaw episodes, the number of rockfalls which occur when there is no freeze-thaw, and then the number of those which occurs during freeze-thaw (neglecting the rockfalls due to rain, because they are much less frequent and precipitation is snow during freezing periods). An estimate of the rockfall frequency during freeze-thaw episodes can then be obtained by dividing the number of rockfalls during freeze-thaw by the effective duration of freeze-thaw. A value of 0.147 [0.127-0.167] rockfalls $^{-1}$ is obtained, which is 7 [4-15] times higher than without freeze-thaw or rainfall. In the same way, one can obtain an estimate of the rockfall frequency during rainfall episodes by considering only the periods without freeze-thaw. In this case, a simple regression can be carried out, giving a constant of $0.012 \mathrm{~h}^{-1}$ (Fig. 8). However, the determination coefficient is low. A value of 0.054 rockfalls $^{-1}$ is obtained for the rockfall frequency during rainfall, which is 4.5 higher than without rainfall. However, it should be noted that this value is obtained from a poor-quality regression and the hypothesis of no rainfall influence cannot be rejected.

A similar analysis has been carried out keeping only the rockfalls bigger than $0.1 \mathrm{~m}^{3}$. The influence factors become 5.8 (instead of 7) for freeze-thaw and 6.5 (instead of 4.5) for rainfall. Again the hypothesis of no rainfall influence cannot be rejected. According to the uncertainties, no significant conclusion can be drawn.

\subsection{Results on DB2}

Out of the 214 rockfalls forming DB2, we have studied 144 rockfalls, whose date is known with an uncertainty lower than $20 \mathrm{~h}$. This choice induces a bias because the rockfalls occurring during freeze-thaw periods are dated with a higher uncertainty (associated with snow cover, ice cover or fog, which disturb the identification of scars on the photographs). It follows that the rockfall frequency during freeze-thaw pe- 

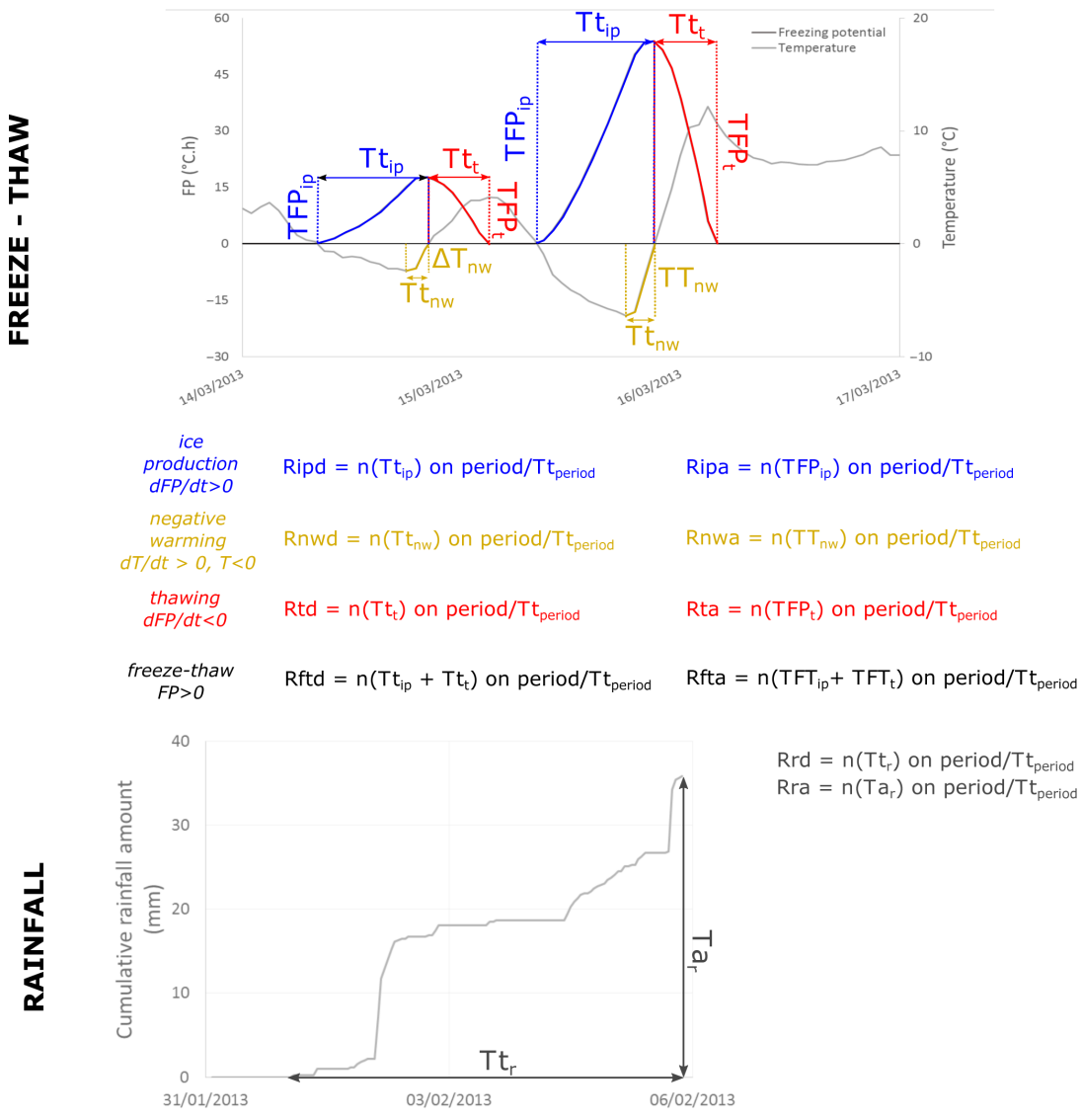

Figure 6. Description of ratios used to quantify freeze-thaw and rainfall amount and duration for each dating period of the DB1. These ratios are used for the multiple linear regression.

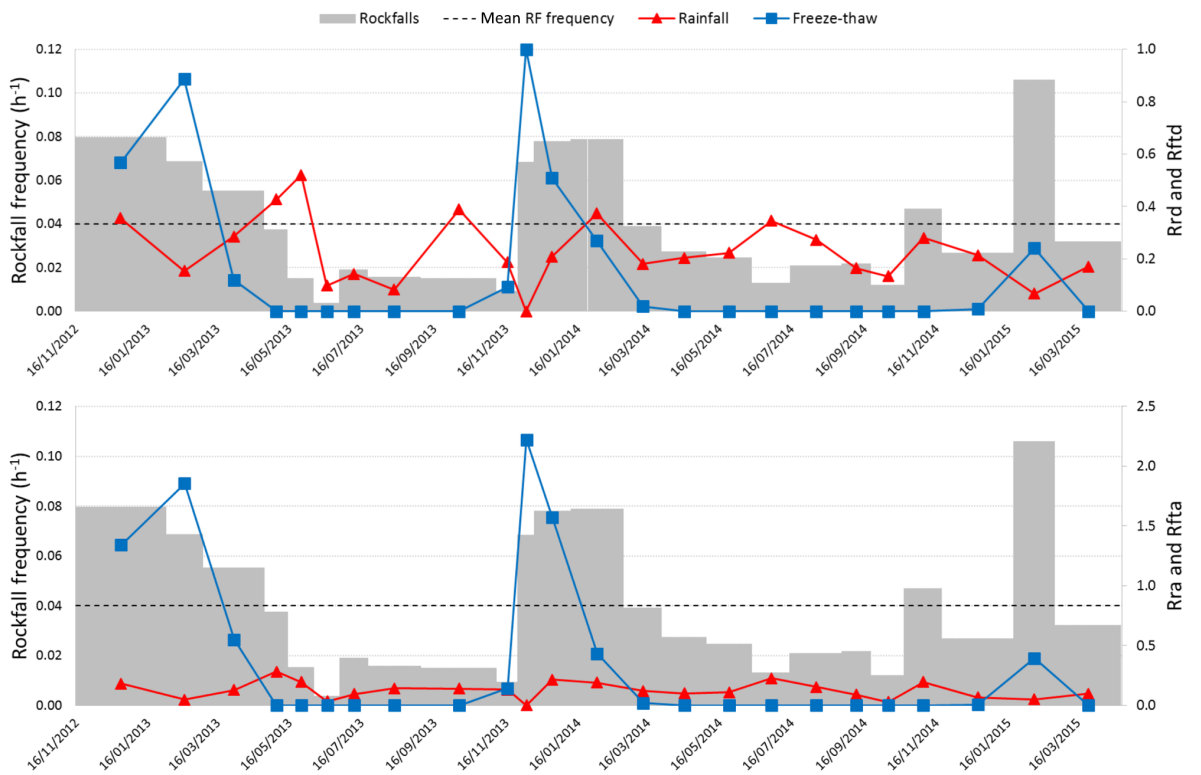

Figure 7. Rockfall frequency for the different observation periods, with rainfall and freeze-thaw duration ratios (up) or rainfall and freezethaw amount ratios (down). 
Table 4. Multiple linear regression values, considering rainfall and freeze-thaw, and rainfall and thaw only.

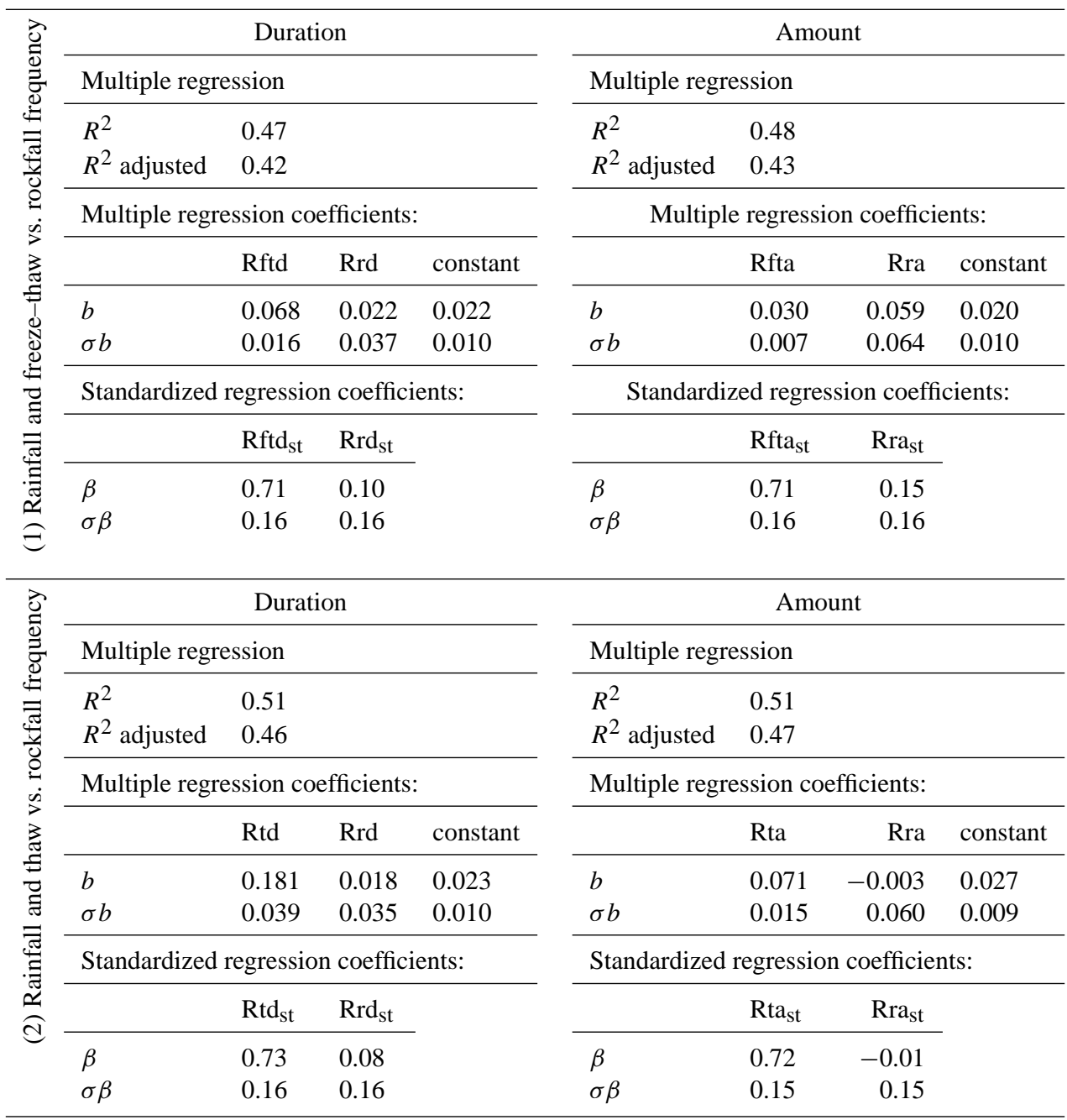

Table 5. "Certain" and "statistical" rockfall frequencies based on the DB2 for different meteorological conditions.

\begin{tabular}{lcccccc}
\hline & Duration $(\mathrm{h})$ & \multicolumn{2}{c}{ Certain frequency } & & \multicolumn{2}{c}{ Statistical frequency } \\
\cline { 3 - 4 } \cline { 6 - 7 } & & $\begin{array}{c}\text { Number of } \\
\text { rockfalls }\end{array}$ & $\begin{array}{c}\text { Rockfall } \\
\text { frequency } \\
\left(\mathrm{h}^{-1}\right)\end{array}$ & & $\begin{array}{c}\text { Number of } \\
\text { rockfalls }\end{array}$ & $\begin{array}{c}\text { Rockfall } \\
\text { frequency } \\
\left(\mathrm{h}^{-1}\right)\end{array}$ \\
\hline Complete period & 19440 & 98 & 0.0050 & & 144 & 0.0074 \\
Rainfall episodes & 4282 & 51 & 0.0119 & & 62 & 0.0145 \\
$\quad$ within 24h after rainfall & 3288 & 9 & 0.0027 & & 21 & 0.0064 \\
$\quad$ 24-48 h after rainfall & 3288 & 8 & 0.0024 & & 19 & 0.0058 \\
$\quad$ 48-72 h after rainfall & 3288 & 2 & 0.0006 & & 8 & 0.0024 \\
Freeze-thaw episodes & 2084 & 14 & 0.0067 & & 25 & 0.0120 \\
No meteorological factor & 3243 & 14 & 0.0043 & & 18 & 0.0056 \\
\hline Rainfall and freeze-thaw & 221 & 0 & 0.0000 & & 1 & 0.0045 \\
\hline Negative cooling periods & 846 & 2 & 0.0024 & & 8 & 0.0095 \\
Negative warming periods & 374 & 2 & 0.0053 & & 5 & 0.0134 \\
Thawing periods & 864 & 10 & 0.0116 & & 12 & 0.0139 \\
\hline
\end{tabular}




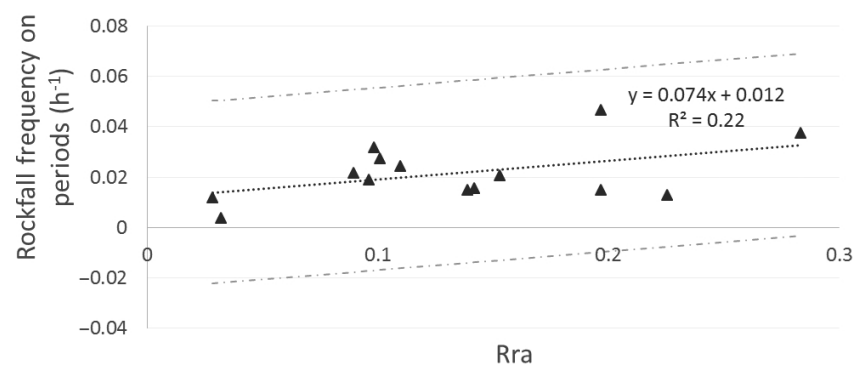

Figure 8. Simple linear regression between rainfall amount ratio (Rra) and rockfall frequency for dating periods without freezethaw. Dashed grey lines: $95 \%$ interval confidence.

riods is underestimated and then DB2 is less relevant than DB1 for comparing the influences of rainfall and freezethaw. But thanks to its higher dating precision, it is possible to study more precisely the influence of the different processes occurring during a freeze-thaw episode, and the period of influence of a rainfall episode.

Different meteorological conditions have been studied. Two types of frequency were considered (Table 5). The "certain" frequencies are obtained by considering only the rockfalls whose the dating interval is entirely included in an episode of freeze-thaw or rainfall, in a period of negative cooling, negative warming or thawing (Fig. 4), within different periods following a rainfall episode $(0-24,24-48$ or 48 $72 \mathrm{~h}$ ) or in a period with none of these conditions. The "statistical" frequencies are obtained by also considering those rockfalls whose dating interval belongs to several meteorological periods. For these rockfalls, the middle of the dating interval has been considered.

It can be seen from Table 5 that the rockfall frequency (certain or statistical) during freeze-thaw episodes or rainfall episodes is clearly higher than in periods with no particular meteorological condition. The frequency during rainfall episodes is even higher than during freeze-thaw episodes, but that is underestimated in DB2. Moreover, it appears that the statistical frequencies within the days following a rainfall episode are not significantly higher than during periods with no particular meteorological condition (they are even lower when considering the certain frequencies).

It appears that during freeze-thaw episodes, rockfalls can occur during the three different types of period, but the rockfall frequency during negative cooling periods is not significantly higher than without any meteorological event (higher for the statistical frequencies, but lower for the certain frequencies). On the other hand, it is clearly higher during negative warming periods and mostly during thawing periods.

The amount and the duration of rainfall since the beginning of the rainfall episode until the compartment falls have been determined for each rockfall that occurred in a rainfall episode. Rockfalls were supposed to occur at the middle of the uncertainty interval. Instantaneous (hourly) rainfall in- tensity and mean rainfall intensity (since the beginning of the episode) have also been determined. For each class of rainfall amount, duration and intensity, rockfall frequency has been determined (Fig. 9).

Considering the rainfall amount, the class $] 30,40] \mathrm{mm}$ shows the highest frequency. Remarkably the frequency decreases for the class ]40,80]. Considering the rainfall duration, the rockfall frequency is the highest for durations shorter than $25 \mathrm{~h}$. It appears that most rockfalls occur during the first $25 \mathrm{~h}$ of a rainfall episode. Remarkably, rainfall durations longer than $50 \mathrm{~h}$ do not trigger more rockfalls than no rain. Considering the rainfall intensity, surprisingly the frequency is the highest for the lowest hourly intensity class. It appears that $1 \mathrm{~h}$ of high-intensity rain is not sufficient to trigger rockfalls. However the mean rainfall intensity appears to be a very significant parameter because the rockfall frequency becomes very high when this parameter exceeds $5 \mathrm{mmh}^{-1}$.

The FP when the rockfall occurred has been determined for each rockfall which occurred in a freeze-thaw episode. Freezing periods (assumed to be ice production periods) and thawing periods have been distinguished (Fig. 10).

It is notable that rockfall frequency is slightly higher for low FP (between 0 and $100^{\circ} \mathrm{Ch}^{-1}$ ) when considering the freezing periods, but is much higher for high FP (400$800^{\circ} \mathrm{Ch}^{-1}$ ) when considering the thawing periods. This suggests that rockfalls occurring during thawing are the most frequent at the beginning of thawing (when the FP is still high) and after a long or intense freezing period. Note that these results are drawn from only 25 rockfalls which occurred during freeze-thaw episodes.

No correlation has been observed between the rockfall frequency and the daily thermal amplitude, the maximal or the minimal daily temperature.

\section{Discussion}

\subsection{Analysis of freeze-thaw influence}

The global influence of freeze-thaw has been analysed from DB1, because DB2 underestimates this influence. Considering DB1, it appears that the rockfall frequency is about 7 times higher during freeze-thaw episodes than without freeze-thaw. To be of practical use in terms of rockfall hazard assessment (Hantz, 2011), the rockfall frequency must be associated with the minimal rockfall volume for which the detection is exhaustive and with the surveyed cliff area. For rockfall volumes larger than $0.05 \mathrm{~m}^{3}$ and for a cliff area of $129646 \mathrm{~m}^{2}$, the rockfall frequency during freeze-thaw episodes has been estimated to be 0.065 rockfalls h$^{-1}$.

DB2 enables us to compare the influence of different types of period during a freeze-thaw episode (Table 5). During freezing periods (negative temperature), our results show that rockfalls occur rather during warming periods than during 

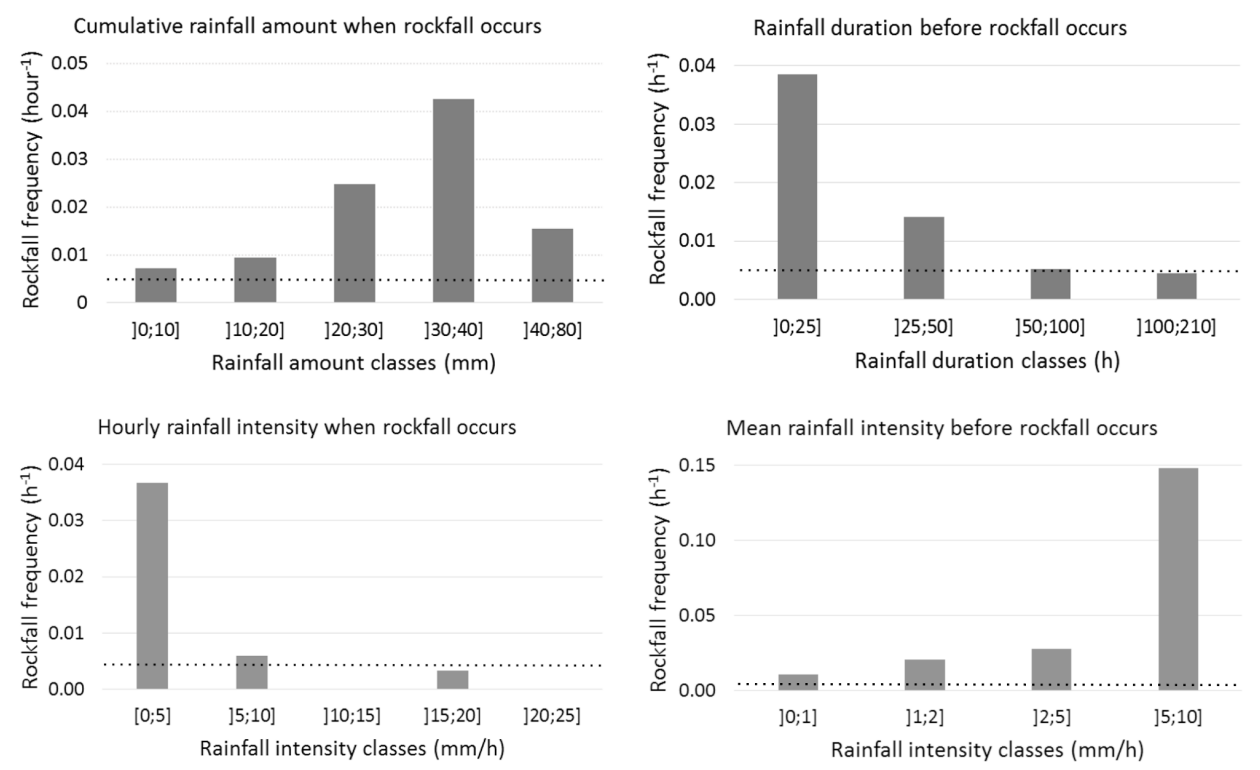

Figure 9. Rockfall frequency for different rainfall amount, rainfall duration and rainfall intensity. Dashed black lines show rockfall frequency without meteorological perturbations.

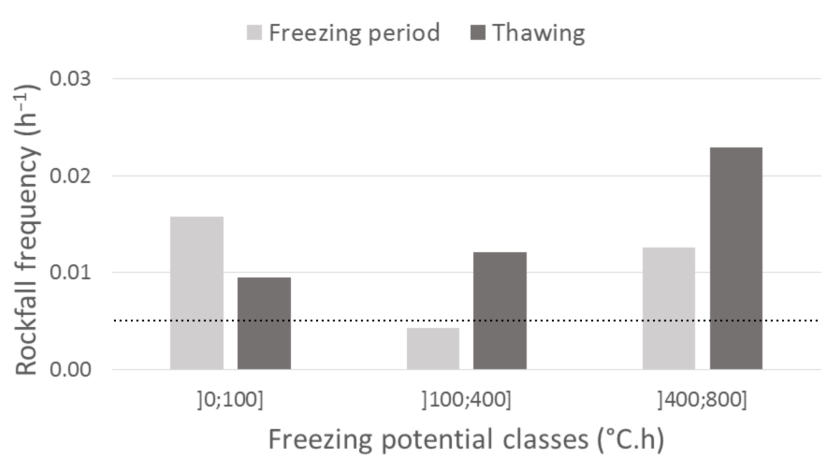

Figure 10. Rockfall frequency according to the freezing potential for freezing periods and thawing periods.

cooling periods. This result is surprising because it is often assumed that the ice influence is due to the pressure exerted by ice during the phase transition (Davidson and Nye, 1985; Bost, 2008). In laboratory, Bost (2008) has measured an ice pressure of several MPa when water freezes in an artificial crack in a limestone block. This pressure decreases with time due to the viscous behaviour of ice, but it increases again when the temperature increases, due to the thermal ice dilatation. It is noteworthy that this test was carried out with a crack which is initially full of water. However, the authors think that this initial condition does not reflect what really happens in the MSE cliff. It appears from field observation that ice forms by an accretion process due to freezing of water drops slowly seeping on rock or ice surface in a non-confined environment (Fig. 11). Note that it is different from that which occurs in permafrost where ice segregation is mainly invoked (Matsuoka, 2001; Dash et al., 2006; Murton et al., 2006). D'Amato (2015) has carried out laboratory tests with different processes of ice formation in artificial cracks or holes in a limestone block. It appears that no pressure is exerted by ice when water is poured progressively in the discontinuity. This result explains why the rockfall frequency is not significantly higher during negative cooling than without meteorological factor. However, negative cooling induces rock contraction, which can result in crack propagation (shrinkage). During negative warming, a crack can propagate due to the expansion of ice, creating an unstable situation. But the rockfall resulting does not necessarily occur immediately because the cohesion or tensile strength of the ice-rock interface (Fiorio et al., 2002) may be sufficient to maintain the rock compartment until the ice has melted. Then rockfalls due to ice thermal expansion may be delayed and occur during the thawing period. However, Davies et al. (2000) and Gunzel $(2008,2012)$ have shown that the shear strength of ice-filled discontinuities begins decreasing when the temperature reaches $-5^{\circ} \mathrm{C}$. On the other hand, when a thawing period begins, the ice begins melting at the ice-air interface, but not immediately at the ice-rock interface, and the thermal expansion continues for some time. It follows that the frequency of rockfalls resulting from thermal ice expansion is probably underestimated.

The direct influence of thawing is associated with the production of water (from ice or snow melting), which can act like rainwater.

Several authors have described a correlation between rockfalls and freeze-thaw, using the occurrence of a freeze-thaw cycle (Douglas, 1980; Frayssines and Hantz, 2006; Mateos et al., 2012; Letortu et al., 2013) or the daily minimum tem- 


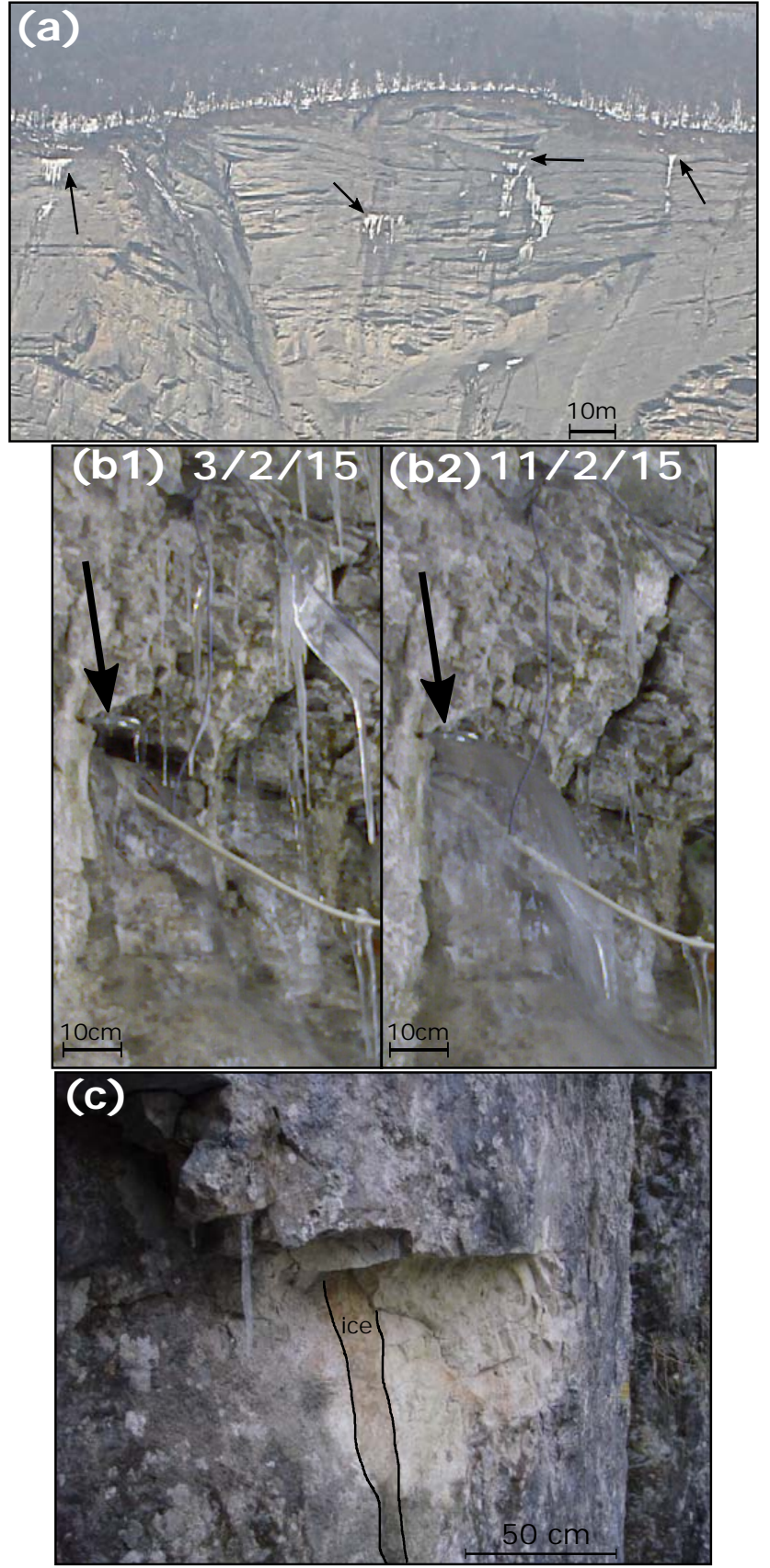

Figure 11. (a) MSE at the beginning of a thawing period. Ice formed by water coming from the forested ledge or from joints is still visible (black arrows). (b) Photographic survey of a crack in the Vercors Massif. (b1) The crack is still open. (b2) The crack is totally filled with ice. (c) Ice slab on a rockfall scar (Vercors Massif).

perature (Delonca et al., 2014). From the data of Frayssines and Hantz (2006) related to rockfalls in limestone cliffs of the French subalpine ranges with volumes between 10 and $10^{5} \mathrm{~m}^{3}$, one can derive that the rockfall frequency is 2.4 times higher on days with freeze-thaw than on days without freeze-thaw (and 1.7 times the mean frequency). Delonca et al. (2014) determined the rockfall frequency for rock cliffs in magmatic rocks (Auvergne, France) and rockfall volumes between 2 and $6000 \mathrm{~m}^{3}$. The daily rockfall frequency 2 days after a strong freezing $\left(-20^{\circ} \mathrm{C}<T<-10^{\circ} \mathrm{C}\right)$ is 3.9 times higher than the frequency without freezing (3.4 times the mean frequency). These factors should be smaller if one considers the frequency 2 days after a freezing day $\left(T<0{ }^{\circ} \mathrm{C}\right)$ but they are not given by Delonca et al. (2014). The influence factors obtained by Frayssines and Hantz (2006) and Delonca et al. (2014) are smaller than the influence factors we derived from DB1, which are of 7 (and 3.7) (Table 6). This can be explained by different rock mass characteristics or/and the different rockfall volume ranges. It would not be surprising to find that the influence of air temperature decreases when the volume (and the depth) of the rockfalls increases.

The overall influence of freeze-thaw on rockfalls appears to be clearly recognized, but the influences of the different phases of freeze-thaw are not well known. In Alpine high mountains, Francou (1982) observed that the rockfall activity in a north-facing wall is maximal in spring when the number of freeze-thaw cycles is maximal, and minimal in winter when the temperature is rarely positive. Sandersen et al. (1996) have shown that the rockfall activity (volume $<1000 \mathrm{~m}^{3}$ ) in Norwegian mountains is maximal in early spring when the temperature increases and lower in winter when the temperature is the lowest. Matsuoka and Sakai (1999) observed the maximal rockfall activity in the Hosozawa cirque (Japanese high mountain) 5-15 days after the melt out of the cirque wall, which represents the delay for thaw penetration to a depth of about $1 \mathrm{~m}$. It appears from these results that a temperature increase causes more rockfalls than freezing, which is consistent with our results. By using the FP, our study suggests a quantitative method to estimate the duration of thawing and then of the most active period for rockfalls.

At a multi-year scale, several authors have observed that permafrost thawing due to climate change increases the rockfall frequency in high mountain cliffs, especially during extremely warm summers as in 2003 (Ravanel, 2010; Huggel et al., 2012). From these observations, it is difficult to identify the processes which have caused the rockfalls.

\subsection{Analysis of rainfall influence}

The influence of rainfall on rockfall occurrence has not been clearly established from DB1 but the analysis of DB2 has shown that rainfall frequency during rainfall episodes is 2.53 times higher than without meteorological event (Table 5). But this influence factor is higher at the beginning of a rainfall episode (Fig. 7): it amounts to 7 in the first $25 \mathrm{~h}$ and then decreases to about 1 after $50 \mathrm{~h}$. Considering the mean intensity since the beginning of the episode, the influence factor amounts to 27 if the intensity is higher than $5 \mathrm{~mm} \mathrm{~h}^{-1}$. Considering the rainfall amount, it amounts to 7.5 if the rainfall amount is between 30 and $40 \mathrm{~mm}$. 
Table 6. Influence factors for different situations. Factor 1 is related to the mean frequency of rockfalls. Factor 2 is related to the frequency without rainfall or freeze-thaw.

\begin{tabular}{lccc}
\hline Approach & Statistical & Statistical & Certain \\
\hline Database & DB1 & DB2 & DB2 \\
\hline Volume range $\left(\mathrm{m}^{3}\right)$ & $0.01-10^{3}$ & $0.1-10^{3}$ & $0.1-10^{3}$ \\
Rockfall number & 854 & 144 & 98 \\
Mean frequency $\left(\mathrm{h}^{-1}\right)$ & 0.04 & 0.0074 & 0.005 \\
Frequency without rainfall or freeze-thaw $\left(\mathrm{h}^{-1}\right)$ & 0.021 & 0.0056 & 0.0043 \\
\hline Frequency during freeze-thaw $\left(\mathrm{h}^{-1}\right)$ & 0.147 & bias & bias \\
$\quad$ Freeze-thaw factor 1 & 3.7 & bias & bias \\
$\quad$ Freeze-thaw factor 2 & 7.0 & bias & bias \\
\hline Frequency during rainfall $\left(\mathrm{h}^{-1}\right)$ & bias & 0.0145 & 0.0119 \\
$\quad$ Rainfall factor 1 & bias & 2.0 & 2.4 \\
$\quad$ Rainfall factor 2 & bias & 2.6 & 2.8 \\
\hline Mean frequency for periods without freeze-thaw $\left(\mathrm{h}^{-1}\right)$ & 0.022 & - & - \\
Frequency without rainfall for periods without freeze-thaw $\left(\mathrm{h}^{-1}\right)$ & 0.012 & - & - \\
Frequency during rainfall for periods without freeze-thaw $\left(\mathrm{h}^{-1}\right)$ & 0.054 & - & - \\
$\quad$ Rainfall factor 1 & 2.5 & - & - \\
$\quad$ Rainfall factor 2 & 4.5 & - & - \\
\hline Frequency for mean rainfall intensity $>$ 5 mm $\mathrm{h}^{-1}$ & - & 0.15 & - \\
$\quad$ Rainfall factor 1 & - & 20.3 & - \\
$\quad$ Rainfall factor 2 & - & 26.8 & - \\
\hline
\end{tabular}

The influence of rainfall has been also shown by several authors (Chau et al., 2003; Mateos et al., 2012; Delonca et al., 2014). From a database with a daily precision, Delonca et al. (2014) determined rockfall frequency for different rainfall conditions and for two transportation routes in Burgundy and La Réunion (France), with respectively limestone and volcanic rocks. They found that the most influential parameters are respectively the rainfall fallen in a 3-day or 2-day interval including the day of the rockfall. This means that the corresponding rainfall periods are statistically 2 days or 1 day long. At the MSE, we found an influence of the rain fallen in rainfall episodes whose length varies between 15 and $205 \mathrm{~h}$ (Fig. 5). Considering rainfall episodes, $75 \%$ of rainfall episodes have a duration between 0 and $50 \mathrm{~h}$, which corresponds to 1-2 days with rainfall, as also shown in Delonca et al. (2014).

From the results of Delonca et al. (2014) for the limestone cliffs, it can be derived that the mean annual rockfall frequency is multiplied by 6 when the rainfall intensity of the 2day rainfall period preceding the rockfalls is between 1.5 and $3 \mathrm{~mm} \mathrm{~h}^{-1}$ (maximal value observed). For the volcanic cliffs, the mean annual rockfall frequency is multiplied by 8 when the rainfall intensity of the 2-day rainfall period preceding the rockfalls is between 5 and $8 \mathrm{mmh}^{-1}$, and this influence factor decreases for higher rainfall intensities. In our study, we have found an influence factor of 20 when the rainfall intensity since the beginning of the rainfall episode is between 5 and $10 \mathrm{mmh}^{-1}$ (Table 6). The MSE seems more sensitive to rainfall than the La Réunion cliffs. This may be due to the different characteristics of the rock masses and to the different rockfall volume ranges (over $0.1 \mathrm{~m}^{3}$ for our DB2, over $2 \mathrm{~m}^{3}$ for La Réunion). Comparing the MSE and Burgundy is more difficult because the intensity intervals are very different. However, if one assumes that the frequency increases linearly with the rainfall intensity, it appears that the sensibilities of both sites are close to each other.

In rock slope design, the influence of water on slope stability is usually modelled by a pressure exerted by water which partially fills the joints (Hoek and Bray, 1981). This process requires that the joints be sealed so that water level can rise. In the MSE cliff, this situation seems very improbable because the joints are sufficiently permeable to allow water to flow outside the rock mass. The authors suggest that water acts by chemical weathering including limestone dissolution and weathering of thin marly layers.

\subsection{Other causes of rockfalls}

It can be seen in Table 6 that the frequency of rockfalls occurring outside rainfall or freeze-thaw episodes has been estimated to $0.021 \mathrm{~h}^{-1}$ from DB1. These rockfalls are caused by other factors, but these factors also act during rainfall or freeze-thaw. The number of rockfalls they have caused can be determined by multiplying the last frequency by the length of the observation period. This represents $52 \%$ of the 854 rockfalls that occurred. Earthquakes are often cited as 
a frequent cause of rockfalls, but this does not appear to be significant at the MSE: none of the 89 stronger earthquakes (magnitude range 1-4.9) which occurred in the Alpine region falls in one of the rockfall dating intervals $(<20 \mathrm{~h})$ of DB2. Other possible processes which can be invoked for causing the MSE rockfalls are tectonic deformations and microcrack propagation. Progressive microcrack propagation which occurs during tertiary creep (Scholz, 1968) appears to be the main cause of rockfalls occurring outside rainfall or freezethaw episodes. Sandersen et al. (1996) also noted that many rockfalls are not correlated with meteorological factors.

\subsection{The problem of close rockfalls}

When studying the rockfall frequency or the rockfall volumes from periodic surveys, the question arises of whether a rock volume has fallen in one or several events (Abellan et al., 2010). Ideally, a truly continuous survey should be required to distinguish events which are close to each other. In the more favourable periods, our method makes it possible to distinguish events which are as close as $10 \mathrm{~min}$. From the 854 rockfall scars detected between 2012 and 2015, less than $1 \%$ have been found to result from several distinct rockfalls. Moreover, all the 214 rockfall scars which have been more precisely dated in DB2 appear as single events in both cases. This means that a rockfall is rarely followed by an adjacent one occurring in the next hours, days or weeks.

Francou (1982) and Krautblatter et al. (2009) also pointed out the storage effect which causes secondary rockfalls. In our case, as we work with the fallen compartment directly detected on the rock face, we know the rupture configuration of the compartment, and we date the moment between the presence/absence of the compartment on the cliff, without considering the deposits.

\subsection{Dating precision of rockfall inventories}

Comparison of results obtained with DB1 and DB2 shows the necessity of a precise rockfall database to study the influence of different meteorological and physical triggering processes. We show that combining TLS detection and photographic survey allows to create more precise temporal inventories and to collect a significant number of events occurring in a precise geological and climatic context. This avoids bias which often occur in databases including rockfalls which have occurred in different sites. Interesting results could be obtained by applying this methodology to other sites in different geological and climatic conditions.

\subsection{Temporal prediction of the rockfall frequency}

It can be seen from Table 5 that the rockfall frequency rapidly falls down to its "base" level (i.e. rockfall frequency without rainfall or freeze-thaw) in a matter of hours (much less than $25 \mathrm{~h}$ ) after a rainfall episode. It can also be seen in Fig. 5 that the thawing periods are usually shorter than $25 \mathrm{~h}$. A simple rule can be drawn from these observations: the rockfall frequency in the MSE is not influenced by the meteorological factors 1 day after the end of rainfall or freezing. On the other hand, one can consider that the rockfall frequency begins to increase at the beginning of rainfall and when the temperature increases during a freezing period.

Our results make it possible to propose a more precise temporal frequency prediction based on meteorological parameters. We suggest the following frequency levels, which correspond to different values of the influence factor (with respect to the frequency without rainfall or freeze-thaw):

- low frequency: no rainfall or freeze-thaw episode in progress for at least $24 \mathrm{~h}$;

- medium frequency (influence factor $>4$ ): during negative warming, thawing (defined using the freezing potential) or if the cumulative rainfall since the beginning of the rainfall episode is higher than $20 \mathrm{~mm}$;

- high frequency (influence factor $>16$ ): rainfall intensity since the beginning of the rainfall episode higher than $5 \mathrm{mmh}^{-1}$.

\section{Conclusion}

The terrestrial laser scanner associated with the photographic survey makes it possible to study precisely the influence of meteorological factors on rockfall occurrence. Rockfalls bigger than $0.01 \mathrm{~m}^{3}$ can be dated with a monthly precision and rockfalls bigger than $0.1 \mathrm{~m}^{3}$ with an hourly precision (or daily precision by cloudy weather).

Rainfall or freeze-thaw appears to have caused about half of the 854 rockfalls which occurred during 887 days, but these rockfalls are concentrated in short periods. These periods have been precisely defined, allowing a quantitative prediction of the rockfall frequency depending on the weather forecast. Rockfalls caused by rainfall occur without significant delay after the last rainfall of the episode. Rockfalls caused by freeze-thaw mainly occur when the air temperature increases and until the freezing potential decreases to zero. It can be inferred that rockfalls are triggered by thermal ice dilatation rather than by dilatation due to the phase transition. But they generally occur only when the ice has melted, because the cohesion of the ice-rock interface can be sufficient to hold the rock compartment which has been cut.

The rockfall frequency can be multiplied by an influence factor as high as 7 during freeze-thaw episodes and 26 when the mean rainfall intensity (since the beginning of the rainfall episode) is higher than $5 \mathrm{mmh}^{-1}$. Based on our results, a three-level frequency scale has been proposed for hazard prediction. 
Acknowledgements. The authors thank the Région Rhône Alpes and Fédération VOR for funding, Météo France and Pierre Hyvrard for providing meteorological data and Gerald Kluczynski for allowing us to take pictures from his property.

Edited by: T. Glade

Reviewed by: R. Poisel and J. Corominas

\section{References}

Abellan, A., Calvet, J., Vilaplana, J. M., and Blanchard, J.: Detection and spatial prediction of rockfalls by means of terrestrial laser scanner monitoring, Geomorphology, 119, 162-171, doi:10.1016/j.geomorph.2010.03.016, 2010.

Abellan, A., Oppikofer, T., Jaboyedoff, M., Rosser, N. J., Lim, M., and Lato, M. J.: Terrestrial laser scanning of rock slope instabilities, Earth Surf. Proc. Land., 39, 80-97, doi:10.1002/esp.3493, 2014.

Bertrand-Krajewski, J.: Cours d'hydrologie urbaine. Partie 2: La pluie, URGC-INSA, Lyon, 2007.

Bost, M.: Altération par le gel des massifs rocheux: etude expérimentale et modélisation des mécanismes de génération des contraintes dans les fissures, $\mathrm{PhD}$ thesis, Ecole Nationale des Ponts et Chaussées, Paris, 2008.

Brázdil, R., Šilhán, K., Pánek, T., Dobrovolný, P., Kašičková, L., and Tolasz, R.: The influence of meteorological factors on rockfall in the Moravskoslezské Beskydy Mts, Geografie - Sborník České geografické společnosti, Praha, 117, 1-20, 2012.

Chanut, M. A., Barthelet, V., and Kasperski, J.: Contribution de l'imagerie de face pour l'analyse des mouvements de terrain: application au versant de Séchilienne, Journées Aléas Gravitaires, Strasbourg, 2011.

Chardon, M.: Excursion géographique: la Chartreuse, Rev. Geogr. Alp., 75, 315-351, doi:10.3406/rga.1987.2687, 1987.

Chau, K. T., Wong, R. H. C., Liu, J., and Lee, C. F.: Rockfall hazard analysis for Hong Kong based on rockfall inventory, Rock Mech. Rock Eng., 36, 383-408, doi:10.1007/s00603-002-0035-z, 2003.

Cruden, D. and Varnes, D. J.: Landslides types and processes, in: Landslides: Investigation and Mitigation, edited by: Turner, A. K. and Schuster, R. L., Transportation Research Board, Washington, D.C., 247, 36-75, 1996.

D'Amato, J.: Apport des bases de données d'éboulements rocheux obtenues par scanner laser dans la caractérisation des conditions de rupture et processus associés, Université Grenoble Alpes, Grenoble, 2015.

Dash, J. G., Rempel, A. W., and Wettlaufer, J. S.: The physics of premelted ice and its geophysical consequences, Rev. Mod. Phys., 78, 696-734, doi:10.1103/RevModPhys.78.695, 2006.

Davidson, G. P. and Nye, J.: A photoelastic study of ice pressure in rock cracks, Cold. Reg. Sci. Technol., 11, 141-153, 1985.

Davies, M. C. R., Hamza, O., Lumsden, B. W., and Harris, C.: Laboratory measurement of the shear strength of ice-filled rock joints, Ann. Glaciol., 31, 463-467, 2000.

Delonca, A., Gunzburger, Y., and Verdel, T.: Statistical correlation between meteorological and rockfall databases, Nat. Hazards Earth Syst. Sci., 14, 1953-1964, doi:10.5194/nhess-14-19532014, 2014.
DeRoin, N. and McNutt, S. R.: Rockfalls at Augustine Volcano, Alaska: The influence of eruption precursors and seasonal factors on occurrence patterns 1997-2009, J. Volcanol. Geoth. Res., 211-212, 61-75, doi:10.1016/j.jvolgeores.2011.11.003, 2012.

Douglas, G. R.: Magnitude frequency study of rockfall in co. Antrim, N. Ireland, Earth Surf. Process., 5, 123-129, 1980.

Douguédroit, A. and Saintignon, M. F.: Les gradients de températures et de précipitations en montagne, Rev. Geogr. Alp., 72, 225-240, doi:10.3406/rga.1984.2566, 1984.

Fiorio, B., Meyssonnier, J., and Boulon, M.: Experimental study of the friction of ice over conrete under simplified icestructure interaction conditions, Can. J. Civil Eng., 29, 347-359, doi:10.1139/L02-012, 2002.

Francou, B.: Chutes de pierres et éboulisation dans les parois de l'étage périglaciaire, Rev. Geogr. Alp., 70, 279-300, doi:10.3406/rga.1982.2508, 1982.

Frayssines, M. and Hantz, D.: Failure mechanisms and triggering factors in calcareous cliffs of the Subalpine Ranges (French Alps), Eng. Geol., 86, 256-270, doi:10.1016/j.enggeo.2006.05.009, 2006.

Gidon, M.: Les décrochements et leur place dans la structuration du massif de la Chartreuse (Alpes occidentales françaises), Rev. Geogr. Alp., 66, 39-55, 1990.

Guerin, A., Hantz, D., Rossetti, J.-P., and Jaboyedoff, M.: Brief communication "Estimating rockfall frequency in a mountain limestone cliff using terrestrial laser scanner", Nat. Hazards Earth Syst. Sci. Discuss., 2, 123-135, doi:10.5194/nhessd-2-1232014, 2014.

Gunzel, F. K.: Shear strength of ice filled rock joints, in: Proceedings of the 9th International Conference on Permafrost, Fairbanks, Alaska, USA, 2008.

Gunzel, F. K.: Shear strength of rock joints filled with frozen sand, in: Proceedings of the 10th International Conference on Permafrost (TICOP), Salekhard, Russia, 2012.

Hale, A. J., Calder, E. S., Loughlin, S. C., Wadge, C., and Ryan, G. A.: Modelling the lava dome extruded at Souffrière Hills Volcano, Montserrat, August 2005-May 2006. Part II: Rockfall activity and talus deformation, J. Volcanol. Geoth. Res., 187, 6984, doi:10.1016/j.jvolgeores.2009.08.014, 2009.

Hallet, B.: Why do freezing rocks break?, Science, 314, 1092-1093, doi:10.1126/science.1135200, 2006.

Hantz, D.: Quantitative assessment of diffuse rock fall hazard along a cliff foot, Nat. Hazards Earth Syst. Sci., 11, 1303-1309, doi:10.5194/nhess-11-1303-2011, 2011.

Hoek, E. and Bray, J. W.: Rock Slope Engineering, The Institution of Mining and Metallurgy, The Institution of Mining and Metallurgy, London, UK, 1981.

Huggel, C., Clague, J. J., and Korup, O.: Is climate Change responsible for changing landslide activity in high mountains?, Earth Surf. Proc. Land., 37, 77-91, doi:10.1002/esp.2223, 2012.

Jaboyedoff, M., Oppikofer, T., Abellan, A., Derron, M.-H., Loye, A., Metzger, R., and Pedrazzini, A.: Use of LIDAR in landslide investigations: a review, Nat. Hazards, 61, 5-28, doi:10.1007/s11069-010-9634-2, 2012.

Jail, M.: Recherches sur les variations thermiques le long d'un adret. Etude statistique et dynamique, Rev. Geogr. Alp., 54, 233-253, doi:10.3406/rga.1966.3257, 1966a.

Jail, M.: Température et types de temps le long d'un adret, Rev. Geogr. Alp., 54, 443-456, doi:10.3406/rga.1966.3271, 1966 b. 
Kobayashi, Y., Harp, E. L., and Kagawa, T.: Simulation of Rockfalls Triggered by Earthquakes, Rock Mech. Rock Eng., 23, 120, 1990.

Krautblatter, M. and Moser, M.: A nonlinear model coupling rockfall and rainfall intensity based on a four year measurement in a high Alpine rock wall (Reintal, German Alps), Nat. Hazards Earth Syst. Sci., 9, 1425-1432, doi:10.5194/nhess-9-1425-2009, 2009.

Letortu, P.: Le recul des falaises crayeuses haut-normandes et les inondations par la mer en Manche centrale et orientale: de la quantification de l'aléa à la caractérisation des risques induits, $\mathrm{PhD}$ thesis, Université de Caen Basse-Normandie, Caen, 2013.

Luckman, B. H.: Rockfalls and rockfall inventory data: some observations from Surprise Valley, Jasper National Park, Canada, Earth Surf. Process., 1, 287-298, 1976.

Malamud, B. D., Turcotte, D. L., Guzzetti, F., and Reichenbach, P.: Landslides, earthquakes and erosion, Earth Planet. Sc. Lett., 229, 45-59, doi:10.1016/j.epsl.2004.10.018, 2004.

Mateos, R. M., Garcia-Moreno, I., and Azanon, J. M.: Freeze-thaw cycles and rainfall as triggering factors of mass movements in a warm Mediterranean region: the case of the Tramuntana Range (Majorca, Spain), Landslides, 9, 417-432, doi:10.1007/s10346011-0290-8, 2012.

Matsuoka, N.: Diurnal freeze-thaw depth in rockwalls: field measurements and theoretical considerations, Earth Surf. Proc. Land., 19, 423-435, 1994.

Matsuoka, N.: Direct observations of frost wedging in alpine bedrock, Earth Surf. Proc. Land., 26, 601-614, 2001.

Matsuoka, N. and Sakai, H.: Rockfall activity from an alpine cliff during thawing periods, Geomorphology, 28, 309-328, 1999.

MELTT - Ministère de l'Equipement, du Logement, des Transports et du Tourisme: Tangentielle Est-Ouest Agglomération Grenobloise. Etude de génie civil et d'environnement des tunnels et tranchées, Phase 1: Analyse des problèmes et de la situation actuelle, Grenoble, 1997.

Montagnat, M., Weiss, J., Cinquin-Lapierre, B., Labory, P. A., Moreau, L., Damilano, F., and Lavigne, D.: Waterfall ice: formation, structure, and evolution, J. Glaciol., 56, 225-234, 2010.

Murton, J. B., Peterson, R., and Ozouf, J.-C.: Bedrock fracture by ice segregation in cold regions, Science, 314, 1127-1129, doi:10.1126/science.1132127, 2006.

Optech: ILRIS-LR Terrestrial Laser Scanner, Summary Specification Sheet, available at: http://www.teledyneoptech.com/ wp-content/uploads/ILRIS-LR-Spec-Sheet-140730-WEB.pdf, last access: 11 December 2015.
Perret, S., Stoffel, M., and Kienholz, H.: Spatial and temporal rockfall activity in a forest stand in the Swiss Prealps - A dendrogeomorphological case study, Geomorphology, 74, 219-231, doi:10.1016/j.geomorph.2005.08.009, 2006.

Rakotomalala, R.: Econométrie: La régression linéaire simple et multiple, 2015.

Ravanel, L.: Caractérisation, facteurs et dynamiques des écroulements rocheux dans les parois à permafrost du massif du Mont Blanc, PhD thesis, Université de Savoie, Chambéry, 2010.

Rosser, N. J., Petley, D., Lim, M., Dunning, S. A., and Allison, R. J.: Terrestrial laser scanning for monitoring the process of hard rock coastal cliff erosion, Q. J. Eng. Geol. Hydroge., 28, 363-375, 2005.

Sandersen, F., Bakkehoi, S., Hestnes, E., and Lied, K.: The influence of meteorological factors on the initiation of debris flows, rockfalls, rockslides and rockmass stability, in: Proceedings of the 7th International Symposium on Landslides, Trondheim, Norway, 17-21 June 1996, 97-114, 1996.

Sass, O. and Oberlechner, M.: Is climate change causing increased rockfall frequency in Austria?, Nat. Hazards Earth Syst. Sci., 12, 3209-3216, doi:10.5194/nhess-12-3209-2012, 2012.

Scholz, C.: Mechanism of creep in brittle rock, J. Geophys. Res., 73, 3295-3302, 1968.

Tharp, T. M.: Conditions for crack propagation by frost wedging, Geol. Soc. Am. Bull., 99, 94-102, 1987.

Viles, H. A.: Linking weathering and rock slope instability: non-linear perspectives, Earth Surf. Proc. Land., 38, 62-70, doi:10.1002/esp.3294, 2013.

Walder, J. and Hallet, B.: A theoritical model of the fracture of rock during freezing, Geol. Soc. Am. Bull., 96, 336-346, 1985.

Wei, L.-W., Chen, H., Lee, C.-F., Huang, W.-K., Lin, M.-L., Chi, C.C., and Lin, H.-H.: The mechanism of rockfall disaster: A case study from Badouzih, Keelung, in northern Taiwan, Eng. Geol., 183, 116-126, doi:10.1016/j.enggeo.2014.10.008, 2014.

Yamagishi, H.: Recent landslides in Western Hokkaido, Japan, Pure Appl. Geophys., 157, 1115-1134, 2000.

Yin, Y., Wang, F., and Sun, P.: Landslide hazards triggered by the 2008 Wenchuan earthquake, Sichuan, China, Landslides, 6, 139151, doi:10.1007/s10346-009-0148-5, 2009. 